\title{
Assessment of Hydrochemical Characters Variations in Relation to Phytoplankton during Pre-monsoon at J-point of Mahi Estuary, Gujarat, India
}

\author{
Nirmal Kumar J.I. ${ }^{*}$, Shamiyan R. Khan ${ }^{2}$, Rita N. Kumar ${ }^{3}$ and P.R. Sajish ${ }^{4}$ \\ ${ }^{1,2}$ P.G. Department of Environmental Science and Technology, Institute of Science and Technology for Advanced \\ Studies and Research, Vallabh Vidya Nagar- 388 120, Gujarat, India \\ ${ }^{3,4}$ Department of Biological and Environmental Sciences, N.V. Patel College of Pure and Applied Sciences, \\ Vallabh Vidya nagar- 388 120, Gujarat, India \\ E-mail: istares2005@yahoo.com
}

Received: 23.09.2013; Accepted: 14.12.2013

\begin{abstract}
Variations of hydro-chemical characters were recorded at three sites of Mahi estuary, near J-point (Lat. $22^{\circ} 10.3^{\prime} \mathrm{N}$ and Long. $72^{\circ} 44.28^{\prime} \mathrm{E}$ ) during the pre-monsoon period. The concentration of the nutrients was relatively high due to the elevated atmospheric temperature, evapo-transpiration of water, slow saline intrusion as well as low inflow of surface water from Mahi River. On the contrary, dissolved oxygen (DO) was at its minimum level during this investigated period. The trophic status of all the three study stations was determined in terms of DO, phosphate, nitrate and sulphate in relation to phytoplankton as key pollution indicators species like Navicula, Nitzchia, Oscillatoria, Scenedesmus, Syndra and others. The results revealed that all the three sites are organically polluted as per the Palmer's species diversity indices.
\end{abstract}

Key words: Water chemistry, dissolve oxygen, trophic status, correlation matrix, Palmer's indices, algae, diatoms

\section{Introduction}

Estuaries are dynamic and fragile ecosystems with varying diversified physico -chemical, geochemical and topographical conditions, and one among the coastal environments like neritic provinces, river deltas, lagoons, mangroves, mudflats and salt marshes. Anthropogenic interventions frequently cause excessive eutrophication in the aquatic environment, such as in estuaries and other coastal regions especially where the circulation is restricted. Several alterations in chemical characteristics and water quality occur as a result of varying tidal intrusion and river-in-flow. Such alt- erations can lead to various ecological consequences like changes in species composition, blooms of phytoplankton, exc-essive nutrient budget and decrease of oxygen concentrations (Pradhan et al., 2009). Dissolved nutrients are the raw materials for the marine trophic chain and estuaries are the main entry for nutrients coming from continental drainage (Martin et al., 2008).

The nutrient supply is greater in estuaries near densely populated regions due to the entry of domestic and industrial waste, urban drainage, and agricultural 


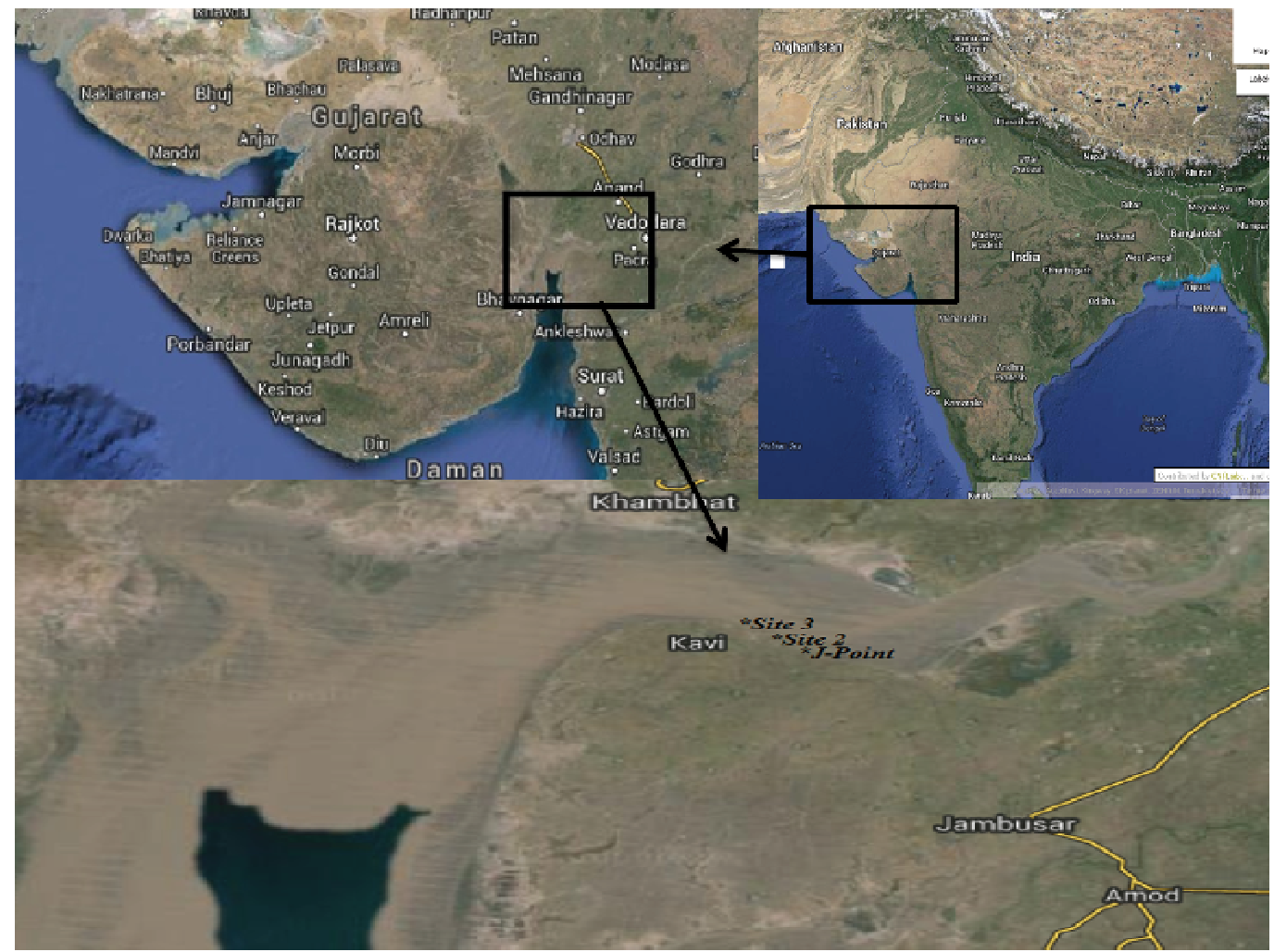

Figure 1. Map showing J-point, Site-2 and Site-3 of Mahi Esturary, Gujarat, India.

runoff. The coastal environments are highly economical, important and are significantly involved in the transport of terrestrial organic matter and associated nutrient elements to the sea for their biogeochemical cycling (Chakrapani, 2005). Physicochemical characteristics in relation to pollution and phytoplankton production potential of brackish water in Sundarbans of India were studied by Shyamalendu et al. (2001). The high nutrient values during the pre-monsoon season were attributed to the lean summer flows and high evapo-transpiration. The water temperature is of enormous significance as it regulates various abiotic characteristics and biotic activities of an aquatic ecosystem (Radhika et al., 2004; Sharma and Sarang, 2004). Tidal variation is more pronounced in tropical than in temperate estuaries (Satpathy et al., 2009). Spatial and temporal fluctuations in water quality of Tapi and Narmada estuarine system were investigated by Nirmal Kumar et al. (2009) and Nirmal Kumar et al. (2010), while an assessment of hydrochemical characteristics with principle component analysis (PCA) of Narmada estuarine region, Gujarat, India was made by Nirmal Kumar et al. (2011). It is evident that most of the water quality parameters are higher during the pre-monsoon period due to the high temperature, high evaporation and low- in- flow of fresh surface water from the river (Radhika et al., 2004; Sharma and Sarang, 2004). The present study deals with ephemeral fluctuations of hydro- 
chemical properties in relation to phytoplankton during pre-monsoon at $\mathrm{J}$ point of Mahi estuary, Gujarat, India.

\section{Materials and methods Study area}

Gulf of Khambhat on the western India has major perennial rivers like Tapi, Narmada, Mahi and many minor rivers. The Mahi River estuary is permanent tropical estuary and one of the major estuaries on the Gulf of Khambhat. The present study was carried out in Mahi estuary at three sites of J-point, Gulf of Khambhat (Fig. 1). The site selection was based on discharge of the effluent from the nearby industrial complexes and distance from the riverine region to the estuarine part. Major industries contributing effluent are chemical, fertilizers, pharmaceutical and petrochemical based. It is rational to presume increased anthropogenic stresses on the estuary at selected sites. Site 1: J-Point is the first site where the effluents from different industrial complexes of Vadodara are directly discharged, which is $22 \mathrm{~km}$ away from the Jambusar town. It is located between $22^{\circ} 10.3^{\prime} \mathrm{N}$ latitude and $72^{\circ} 44.28^{\prime} \mathrm{E}$ longitude. The elevation of the site is $7 \mathrm{~m}$ and is $7 \mathrm{~km}$ upstream to Kavi near lower reaches, while site 2 is $3 \mathrm{~km}$ from j-point towards downstream and $4 \mathrm{~km}$ upstream to Kavi. Site 3 is two kilometres from site 2 towards lower reaches.

\section{Sampling and physico-chemical analysis}

Ephemeral water samples were collected for physico-chemical determination from the three sites at an interval of 15 days during pre-monsoon from $5^{\text {th }}$ May, 2011 to $20^{\text {th }}$ June, 2011, in wide mouth plastic bottles, brought to the laboratory and stored in dark until analysis in the laboratory for a day or two after sample collection. Standard methods were adopted for water analysis (APHA, 1989). Temperature of surface water was determined on-site, dissolve oxygen (DO) was fixed on-site in $300 \mathrm{ml}$ DO bottles and later determined by the alkali-Azide modification of Winkler's technique. Samples for Biological Oxygen Demand (BOD) analysis were also collected simultaneously and fixed at the same time in $300 \mathrm{ml}$ dark BOD bottles. Nitrate was estimated by the cadmium reduction method, phosphate and sulphate by the ascorbic acid and turbid metric method, respectively. High-temperature combustion method was employed for TOC (Total Organic Carbon) analysis and salinity was estimated titramatrically. Correlation analysis was carried out to determine positive and negative correlation between the hydro-chemical parameters. Water samples for phytoplankton were filtered using $20 \mu$ mesh plankton net and collected in clean plastic bottles and preserved in buffered formaldehyde (4\%). Phytoplankton were identified using stereo microscope at $45 \mathrm{X}, 100 \mathrm{X}$ magnification and referring to standard books such as Newell and Newell (1977), Anand (1998), Suthers and Rissik (2009), as well as published literatures and/or research data. Palmer (1969) algal index was calculated to determine the level of organic pollution.

\section{Results and discussion Hydro-chemical characters}

Temperature was encountered in the range between $29^{\circ} \mathrm{C}$ at the time of $4^{\text {th }}$ visit at $\mathrm{J}$ point to $33^{\circ} \mathrm{C}$ at the time of $3^{\text {rd }}$ visit at site- 3 (Fig. 2). The temperature was slightly raised till the $3^{\text {rd }}$ sampling and then there was a fall in the temperature due to monsoon. These results agree with the 
results of Martin et al. (2008), for Cochin estuary of south India where they reported the temperature variation of $28^{\circ} \mathrm{C}$ to $32^{\circ} \mathrm{C}$ during pre-monsoon. The $\mathrm{pH}$ values of surface water were recorded from minimum 7.7 at J-Point on $3^{\text {rd }}$ visit and maximum 8.1 at site- 2 and site- 3 on $1^{\text {st }}$ and $4^{\text {th }}$ visit, respectively. Snow and Taljaard (2007) found not much variation of $\mathrm{pH}$ but shown alkaline throughout the experimental period which is substantiated with present results. DO concentration showed remarkable variations with the range of $3.5 \mathrm{mgL}^{-1}$ at the time of $1^{\text {st }}$ visit at J-Point to $7.2 \mathrm{mgL}^{-1}$ during the $4^{\text {th }}$ visit at site-3. Higher biological activity during the pre-monsoon period could be responsible for this as observed in Chesapeake Bay by Levinton (2001). Lower DO concentrations encountered at J-point could be associated with release of effluents from the Vadodara industrial area (Eyre and Twiggs, 1997).

Phosphate concentration was highest (3.98 $\left.\mu \mathrm{ML}^{-1}\right)$ at the time of $1^{\text {st }}$ visit at JPoint. Nitrate content varied from $16.9 \mu \mathrm{ML}^{-}$ ${ }^{1}$ on $4^{\text {th }}$ visit at site- 3 to $22.74 \mu \mathrm{ML}^{-1}$ on the $1^{\text {st }}$ visit at J-Point. Phosphate and nitrate values were higher at J-Point as effluent is released at this point directly from Vadodara industrial complexes which is corroborated the findings of Ajitkumar et al. (2006), in Mutthupeta mangroves in Tamil nadu. Sulphate content was registered from $2639.1 \mathrm{mgL}^{-1}$ on the $1^{\text {st }}$ visit at site-3. Moving towards J-Point, sulphate concentrations gradually declined being lowest at J-Point $\left(2140.45 \mathrm{mgL}^{-1}\right)$ on $1^{\text {st }}$ visit. Total hardness was encountered in the range of $5500 \mathrm{mgL}^{-1}$ at J-Point to $7340 \mathrm{mgL}^{-1}$ at site-3. Magnesium hardness was the lowest $4196 \mathrm{mgL}^{-1}$ at J-Point at the time of $4^{\text {th }}$ visit and the highest was $5975 \mathrm{mgL}^{-1}$ at site-3 on the $1^{\text {st }}$ visit. Ramnathan et al.
(1988), found similar observations in Cauvery estuary with sulphate, total hardness and magnesium contents greater at lower reaches during pre-monsoon due to tidal ingress of sea water.

Salinity was distributed in the range of $27.01 \mathrm{mgL}^{-1}$ at $\mathrm{J}$-Point during $3^{\text {rd }}$ visit to $34.324 \mathrm{mgL}^{-1}$ at site- 3 at the time of $1^{\text {st }}$ visit. Increase in salinity values recorded during pre-monsoon might be due to low fresh water intrusion and high evapo-transpiration (Govindasamy et al., 2000; Prabu et al., 2008). Chlorinity also followed the similar trend showing highest value at Site 3 in the range of 15.4 to $18.5 \mathrm{mgL}^{-1}$ at the time of $4^{\text {th }}$ and $1^{\text {st }}$ visits, respectively. TOC in surface water was in the range of $12.02 \mathrm{mgL}^{-1}$ on $4^{\text {th }}$ May 2011 at site- 3 to $22.62 \mathrm{mgL}^{-1}$ on $20^{\text {th }}$ June 2011 at J-Point. The Chemical Oxygen Demand (COD) was observed in the range of $490 \mathrm{mgL}^{-1}$ on the $4^{\text {th }}$ visit at site- 3 and the highest COD value observed was $700 \mathrm{mgL}^{-}$ ${ }^{1}$ during the $1^{\text {st }}$ sampling at J-Point. While the BOD at site- 3 on $4^{\text {th }}$ sampling was 1.2 $\mathrm{mgL}^{-1}$, it was $5.4 \mathrm{mgL}^{-1}$ at $\mathrm{J}$-Point during the $1^{\text {st }}$ visit. Overall, salinity, DO, total hardness, sulphate content were higher at site 3. On the contrary, nitrate, phosphate, COD, BOD and TOC were encountered higher at J-Point than at Site -2 and 3 (Figs. 2-3).

The trophic status of J-point in terms of DO concentration (Philipose, 1960) was seen to be eutrophic, whereas sites 2 and 3 were encountered as mesotrophic. Moreover, phosphate content as per Ganapati (1956) and nitrate as per the Likens (1975) revealed that all the three sites were considered to be mesotrophic in nature however, sulphate concentration by Beeton (1965) in all three sites were experienced eutrophic nature (Tab. 1). Data from all three studied sites was pooled. 
Nirmal Kumar J.I., Shamiyan R. Khan, Rita N. Kumar and P.R. Sajish / Our Nature (2013), 11(2): 85-95
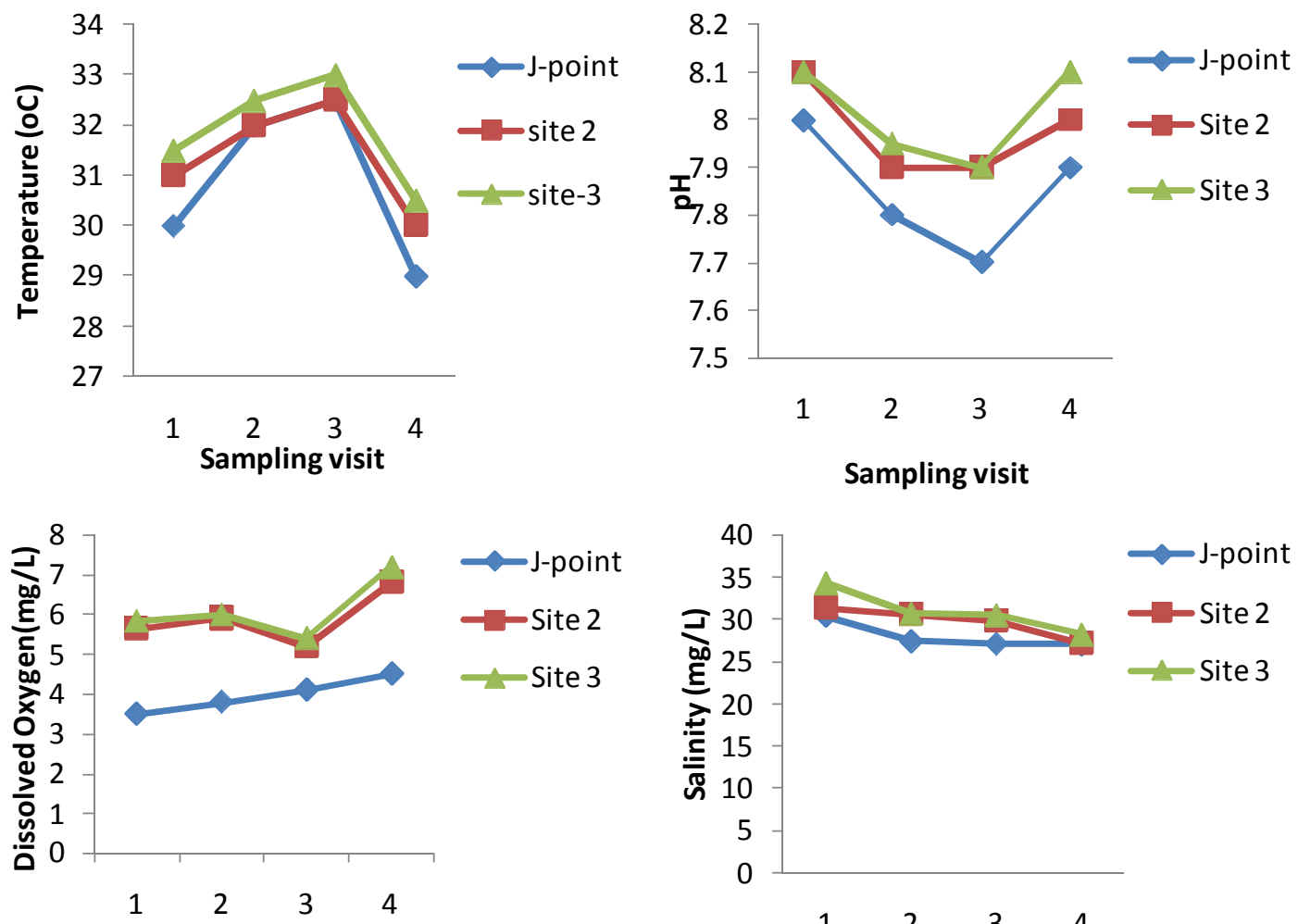

Sampling visit
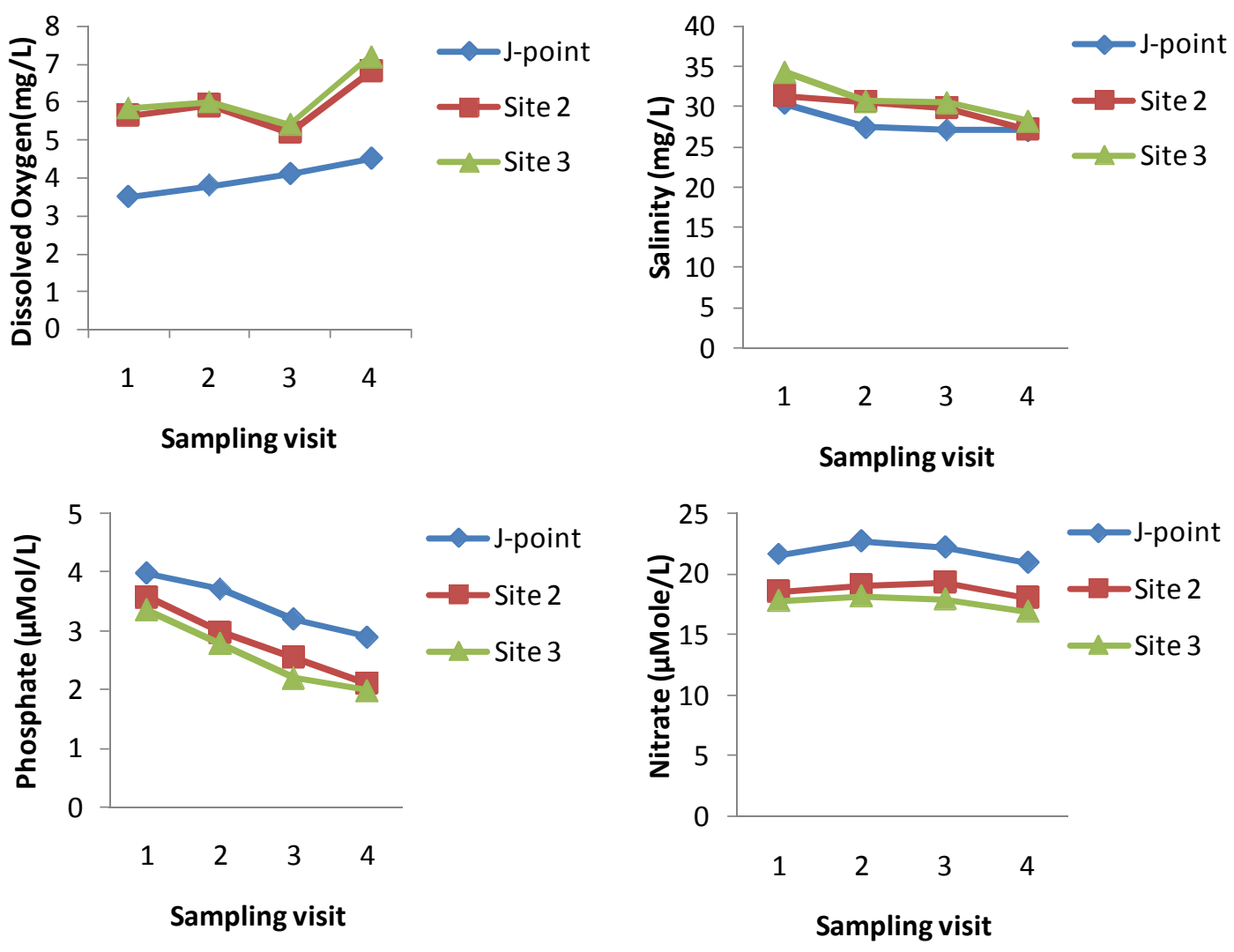
Nirmal Kumar J.I., Shamiyan R. Khan, Rita N. Kumar and P.R. Sajish / Our Nature (2013), 11(2): 85-95

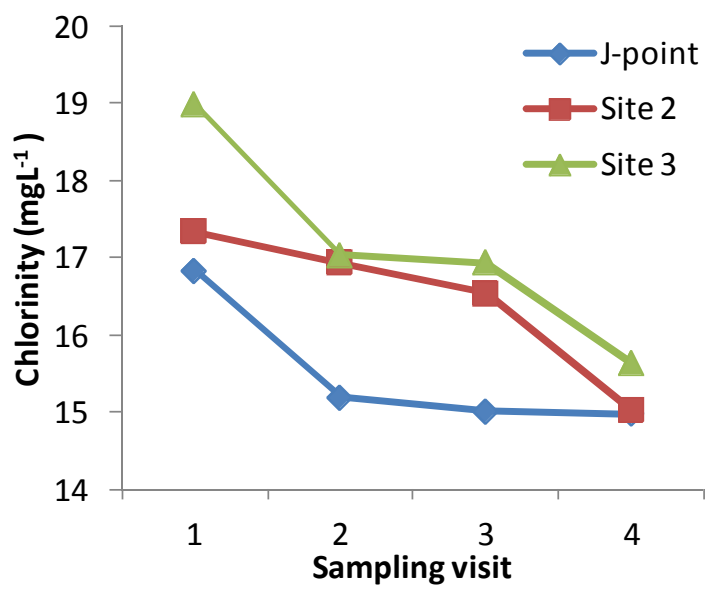

Figure 2. Variation in temperature, $\mathrm{pH}, \mathrm{DO}$, salinity, chlorinity, phosphate and nitrate concentrations at different sampling sites of J-point, Mahi Esturary, Gujarat, India.
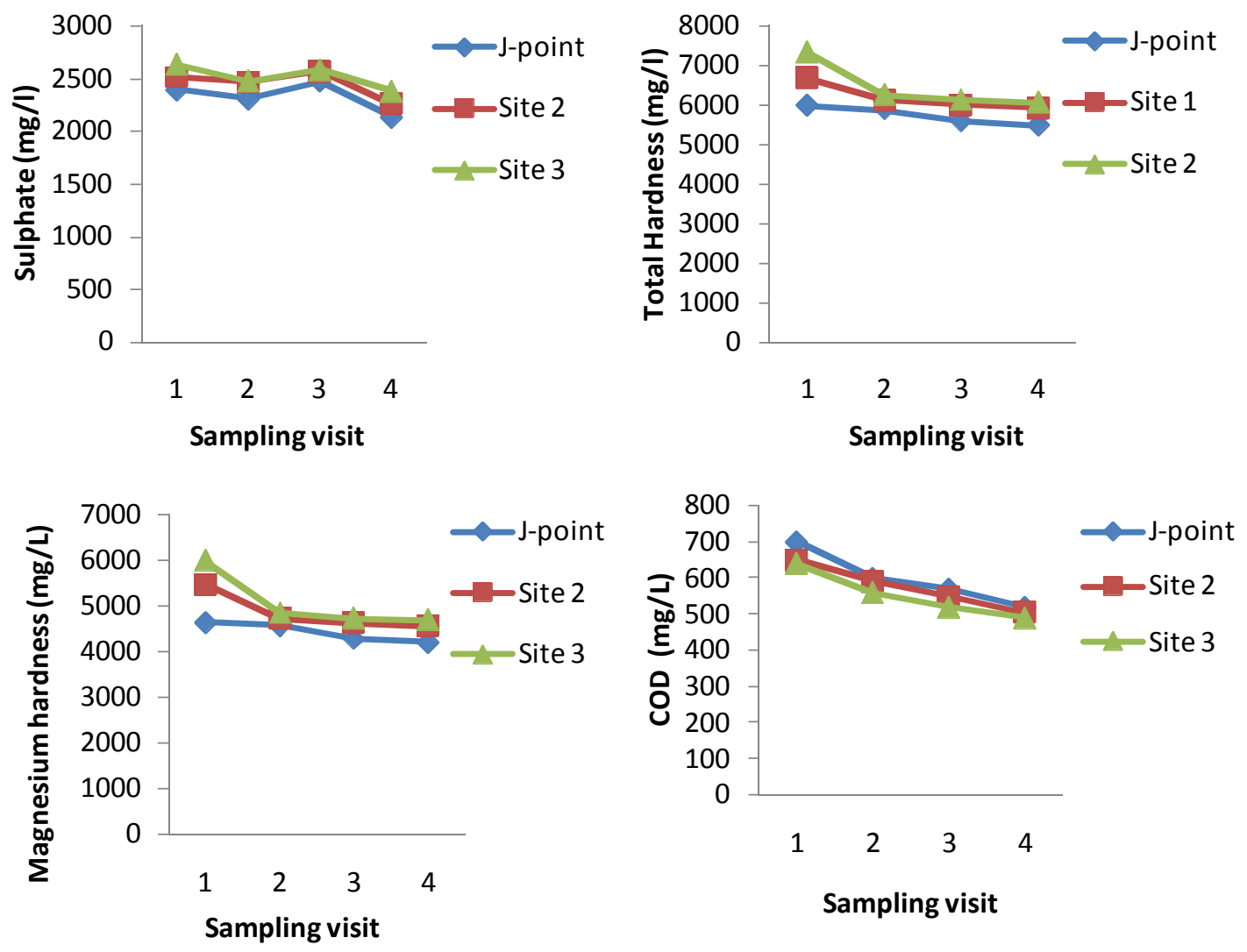

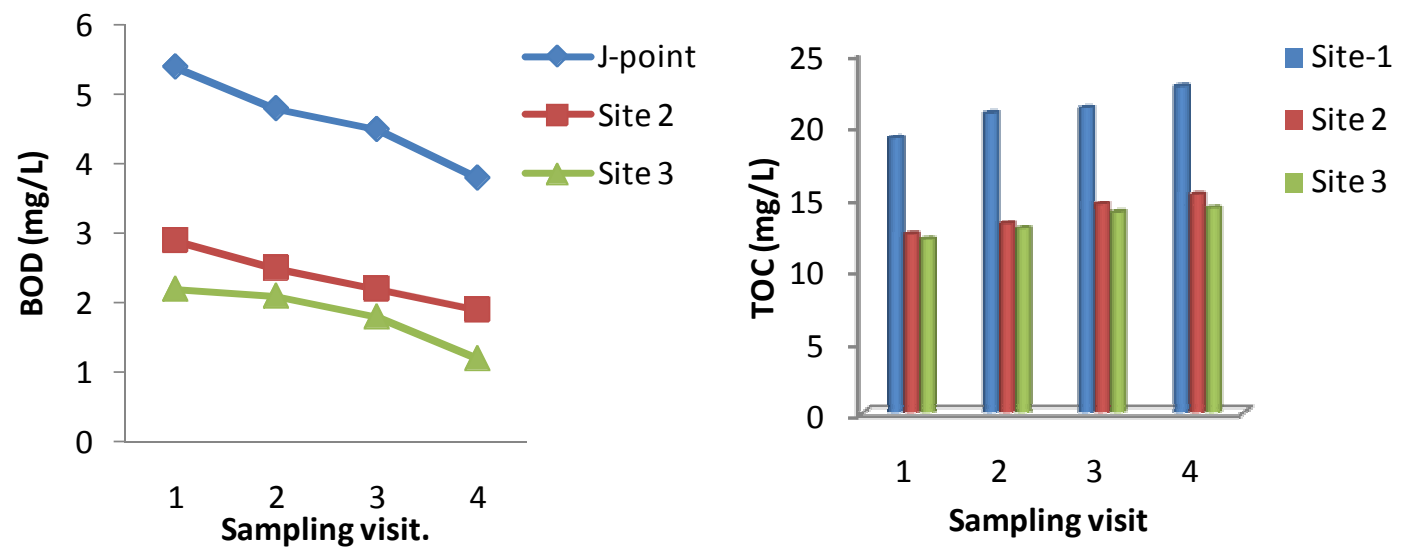

Figure 3. Variation in sulphate, magnesium, total hardness, BOD, COD and TOC concentrations at different sampling sites of J-point, Mahi Esturary, Gujarat, India.

Table 1. Trophic status of the three different sites of Mahi Esturary, Gujarat, India.

\begin{tabular}{|c|c|c|c|c|c|}
\hline Parameters (mg/L) & Range mgl $^{-1}$ & Condition & J-Point & Site-2 & Site-3 \\
\hline \multirow{3}{*}{$\begin{array}{l}\text { D.O. (Philipose, } \\
\text { 1960) }\end{array}$} & 10 above & Oligo & \multirow{3}{*}{$\begin{array}{c}3.9 \\
\text { (Eutro) }\end{array}$} & \multirow{3}{*}{$\begin{array}{c}5.8 \\
\text { (Meso) }\end{array}$} & \multirow{3}{*}{$\begin{array}{c}6.1 \\
\text { (Meso) }\end{array}$} \\
\hline & $5.0-10.0$ & Meso & & & \\
\hline & $0-0.5$ & Eutrophic & & & \\
\hline \multirow{3}{*}{$\begin{array}{l}\text { Phosphate } \\
\text { (Ganapati, 1956) }\end{array}$} & $0.01-0.1$ & Oligo & \multirow{3}{*}{$\begin{array}{c}0.43 \\
\text { (Meso) }\end{array}$} & \multirow{3}{*}{$\begin{array}{c}0.39 \\
\text { (Meso) }\end{array}$} & \multirow{3}{*}{$\begin{array}{c}0.36 \\
\text { (Meso) }\end{array}$} \\
\hline & $0.1-0.5$ & Meso & & & \\
\hline & 0.5 -above & Eutrophic & & & \\
\hline \multirow{3}{*}{$\begin{array}{l}\text { Nitrate } \\
\text { (Likens, 1975) }\end{array}$} & $0.0-0.5$ & Oligo & \multirow{3}{*}{$\begin{array}{c}0.66 \\
\text { (Meso) }\end{array}$} & \multirow{3}{*}{$\begin{array}{c}0.62 \\
\text { (Meso) }\end{array}$} & \multirow{3}{*}{$\begin{array}{c}0.59 \\
\text { (Meso) }\end{array}$} \\
\hline & $0.5-1.5$ & Meso & & & \\
\hline & 1.5-above & Eutrophic & & & \\
\hline \multirow{3}{*}{$\begin{array}{l}\text { Sulphate } \\
\text { (Beeton, 1965) }\end{array}$} & $0.0-20.0$ & Oligo & \multirow{3}{*}{$\begin{array}{c}2333.33 \\
\text { (Eutro) }\end{array}$} & \multirow{3}{*}{$\begin{array}{c}2459.96 \\
\text { (Eutro) }\end{array}$} & \multirow{3}{*}{$\begin{array}{r}2525.77 \\
\text { (Eutro) }\end{array}$} \\
\hline & $20.0-40.0$ & Meso & & & \\
\hline & 40.0-above & Eutrophic & & & \\
\hline
\end{tabular}

together and analyzed to extrapolate the overall correlation among the hydrochemical characters. All the hydro-chemical characters are positively correlated with each other but DO and TOC were negatively correlated to $\mathrm{pH}$, salinity, chlorinity, total hardness, phosphate, COD, BOD in all the three sites (Tabs. 2-4).

\section{Phytoplankton}

Phytoplanktons are regarded as sensitive and rapidly rating indicators due to changes in hydro-chemical characters (Jafari and
Gand, 2006). Estuarine phytoplankton communities usually comprise several taxonomic groups and contribute to primary production and interaction between tropical levels (Roy et al., 2006). Since planktons respond quickly to change nutrients composition, plankton profile can be used for assessment of pollution. The dynamics of phytoplankton are a function of some environmental factors like salinity, temperature and nutrients that can affect species diversity and distribution (Morias et al., 2003). A total of 24 species belonging to 
Table 2. Correlation matrix of Hydro-chemical characters at J-point of Mahi estuary

\begin{tabular}{|c|c|c|c|c|c|c|c|c|c|c|c|c|c|}
\hline J point & Temp & PH & DO & Sal & Chl & TH & MH & Sul & Phos & Nitr & COD & BOD & TOC \\
\hline Temp & 1 & & & & & & & & & & & & \\
\hline $\mathrm{PH}$ & -0.82 & 1 & & & & & & & & & & & \\
\hline DO & -0.26 & -0.33 & 1 & & & & & & & & & & \\
\hline Sal & -0.29 & 0.75 & -0.79 & 1 & & & & & & & & & \\
\hline Chl & -0.29 & 0.75 & -0.79 & 1 & 1 & & & & & & & & \\
\hline TH & 0.15 & 0.43 & -0.96 & 0.76 & 0.76 & 1 & & & & & & & \\
\hline MH & 0.13 & 0.44 & -0.96 & 0.76 & 0.76 & 0.99 & 1 & & & & & & \\
\hline Sul & 0.72 & -0.36 & -0.59 & 0.31 & 0.31 & 0.37 & 0.35 & 1 & & & & & \\
\hline Phos & 0.18 & 0.40 & -0.98 & 0.79 & 0.79 & 0.99 & 0.99 & 0.46 & 1 & & & & \\
\hline Nitr & 0.91 & -0.60 & -0.48 & -0.13 & -0.13 & 0.44 & 0.44 & 0.58 & 0.45 & 1 & & & \\
\hline COD & 0.03 & 0.52 & -0.95 & 0.93 & 0.93 & 0.91 & 0.90 & 0.53 & 0.94 & 0.22 & 1 & & \\
\hline BOD & 0.26 & 0.32 & -0.99 & 0.82 & 0.82 & 0.93 & 0.92 & 0.64 & 0.96 & 0.44 & 0.97 & 1 & \\
\hline TOC & -0.19 & -0.38 & 0.97 & -0.87 & -0.87 & -0.90 & -0.89 & -0.65 & -0.94 & -0.35 & -0.98 & -0.99 & 1 \\
\hline
\end{tabular}

Temp = Temperature, Sal = Salinity, $\mathrm{Chl}=$ Chlorinity, $\mathrm{TH}=$ Total hardness, $\mathrm{MH}=$ Magnesium hardness, $\mathrm{Sul}=$ Sulphate, Phos $=$ Phosphate, Nitr $=$ Nitrate, $\mathrm{COD}=$ Chemical Oxygen Demand, $\mathrm{BOD}=$ Biological Oxygen Demand, TOC $=$ Total Organic Carbon

Table 3. Correlation matrix of Hydro-chemical characters at site- 2 of Mahi estuary.

\begin{tabular}{lccccccccccccc}
\hline Site 2 & Temp & PH & DO & Sal & Chl & TH & MH & Sul & Phos & Nitr & COD & BOD & TOC \\
\hline Temp & 1 & & & & & & & & & & & & \\
PH & -0.66 & 1 & & & & & & & & & & & \\
DO & -0.85 & 0.21 & 1 & & & & & & & & & & \\
Sal & 0.6 & 0.11 & -0.76 & 1 & & & & & & & & & \\
Chl & 0.6 & 0.11 & -0.76 & 1 & 1 & & & & & & & & \\
TH & -0.06 & 0.75 & -0.34 & 0.74 & 0.74 & 1 & & & & & & & \\
MH & -0.12 & 0.8 & -0.3 & 0.68 & 0.68 & 0.99 & 1 & & & & & & \\
Sul & 0.84 & -0.17 & -0.98 & 0.85 & 0.85 & 0.43 & 0.38 & 1 & & & & & \\
Phos & 0.23 & 0.47 & -0.51 & 0.91 & 0.91 & 0.93 & 0.9 & 0.62 & 1 & & & & \\
Nitr & 0.99 & -0.69 & -0.83 & 0.56 & 0.56 & -0.1 & -0.16 & 0.82 & 0.19 & 1 & & & \\
COD & 0.24 & 0.47 & -0.52 & 0.91 & 0.91 & 0.93 & 0.9 & 0.62 & 0.99 & 0.19 & 1 & & \\
BOD & 0.23 & 0.46 & -0.51 & 0.91 & 0.91 & 0.93 & 0.89 & 0.61 & 0.99 & 0.19 & 0.99 & 1 & \\
TOC & 0.67 & -0.52 & -0.67 & 0.04 & 0.04 & -0.35 & -0.34 & 0.56 & -0.26 & 0.69 & -0.25 & -0.27 & 1 \\
\hline
\end{tabular}

Temp = Temperature, Sal = Salinity, Chl = Chlorinity, $\mathrm{TH}=$ Total hardness, $\mathrm{MH}=$ Magnesium hardness, $\mathrm{Sul}=$ Sulphate, Phos = Phosphate, Nitr = Nitrate, $\mathrm{COD}=$ Chemical Oxygen Demand, $\mathrm{BOD}=$ Biological Oxygen Demand, TOC $=$ Total Organic Carbon.

4 genera were encountered during ephemeral study at this tropical estuary. The phytoplanktons were represented by four dominant groups viz. bacillariophyceae, cyanophyceae, chlorophyceae, and dinophyceae represented by $15,4,3$ and 2 species, respectively. Plankton community structure at different sites was found to show marked spatial and temporal variations. Bacillariophyceae was relatively abundant and accounted for $61.66 \%$ of total phytoplankton population, followed by cyanohyceae $(16 \%)$, chlorophyceae (12.66 $\%)$ and dinophyceae $(9.66 \%)$. The percentage contribution of each group is represented by pie-charts (Fig. 4).

Bacillariophyceae members constituted the major bulk to phytoplankton population during all sampling visits. Ekwu and Sikoki (2004) also reported class bacillariophyceae to be the most abundant group of phytoplankton among many tropical 
Nirmal Kumar J.I., Shamiyan R. Khan, Rita N. Kumar and P.R. Sajish / Our Nature (2013), 11(2): 85-95

Table 4. Correlation matrix of Hydro-chemical characters at site-3 of Mahi estuary.

\begin{tabular}{|c|c|c|c|c|c|c|c|c|c|c|c|c|c|}
\hline Site 3 & Temp & PH & DO & Sal & Chl & TH & MH & Sul & Phos & Nitr & COD & BOD & TOC \\
\hline Temp & 1 & & & & & & & & & & & & \\
\hline $\mathrm{PH}$ & -0.92 & 1 & & & & & & & & & & & \\
\hline DO & -0.88 & 0.66 & 1 & & & & & & & & & & \\
\hline Sal & 0.23 & 0.14 & -0.62 & 1 & & & & & & & & & \\
\hline Chl & 0.23 & 0.14 & -0.62 & 1 & 1 & & & & & & & & \\
\hline $\mathrm{TH}$ & -0.14 & 0.49 & -0.29 & 0.92 & 0.92 & 1 & & & & & & & \\
\hline MH & -0.16 & 0.51 & -0.28 & 0.92 & 0.92 & 0.99 & 1 & & & & & & \\
\hline Sul & 0.5 & -0.18 & -0.85 & 0.87 & 0.87 & 0.70 & 0.69 & 1 & & & & & \\
\hline Phos & 0.11 & 0.23 & -0.43 & 0.93 & 0.93 & 0.90 & 0.88 & 0.66 & 1 & & & & \\
\hline Nitr & 0.88 & -0.69 & -0.87 & 0.54 & 0.54 & 0.21 & 0.18 & 0.61 & 0.53 & 1 & & & \\
\hline COD & 0.09 & 0.26 & -0.46 & 0.97 & 0.97 & 0.95 & 0.93 & 0.73 & 0.98 & 0.48 & 1 & & \\
\hline BOD & 0.57 & -0.26 & -0.76 & 0.86 & 0.86 & 0.65 & 0.63 & 0.76 & 0.87 & 0.87 & 0.85 & 1 & \\
\hline TOC & -0.11 & -0.22 & 0.40 & -0.90 & -0.90 & -0.87 & -0.85 & -0.61 & -0.99 & -0.54 & -0.97 & -0.87 & 1 \\
\hline
\end{tabular}

Temp = Temperature, Sal = Salinity, $\mathrm{Chl}=$ Chlorinity, $\mathrm{TH}=$ Total hardness, $\mathrm{MH}=$ Magnesium hardness, $\mathrm{Sul}=$ Sulphate, Phos $=$ Phosphate, Nitr $=$ Nitrate, $\mathrm{COD}=$ Chemical Oxygen Demand, $\mathrm{BOD}=$ Biological Oxygen Demand, $\mathrm{TOC}=$ Total Organic Carbon

estuaries. Perumal et al. (2009) recorded more than $50 \%$ of Bacillariophycean members of phytoplankton diversity of Kaduviyar estuary. During present study highest species of this group showed at middle reaches and lower reaches. This could be due to the role of more salinity (Redekar and Wagh, 2000). Of the diatom species recorded, species belonging to Navicula, Nitzschia and Coscinodiscus occurred at all the three sites throughout investigated period.

Species of cyanophyceae were represented by Anabaena, Merismopedium, Nostoc and Oscillatoria and second merging planktonic groups. The occurrence of this group could be attributed to the high temperature, slightly; alkaline conditions and nutrient rich discharge (Harsha and Malammanavar, 2004). Constant input of wastewater not only contains organic wastes but also silt and other pollutants which might be attributed to higher cyanophyceae at J-point upper reaches (Saxeena and Shrivastava, 2001). Chlorophyceae members were represented by Chlorella,
Scenedesmus, and Stauroneis. Ekwu and Sikoki (2004) in Nigeris estuary reported the dominance of chlorphycean members in middle and upper reaches which substantiate the present findings. Class Dinoflagellates formed the least group having 2 species and their distribution is regulated by salinity, temperature and $\mathrm{pH}$ as their occurrence is more in areas having significant marine water influence (Cremer et al., 2007). The species of bacillariophyceae were higher in number during higher salinity ranges as they are dominant in estuarine environment. The presence of Palmer pollution indicator species like Navicula, Nitzschia, Oscillatoria, Scenedesmus, Syndra, others shown that all the three sites are highly organic polluted (Tab. 5). Somani and Pejaver (2007) recorded similar findings.

\section{Conclusion}

Present study revealed that salinity, DO, total hardness, chlorinity, sulphate contents were higher at site 3 near lower reaches. On the contrary, nitrate, phosphate, COD, BOD 
and TOC were encountered higher at $\mathrm{J}$ Point than at Site -2 and 3 which could be due to low tidal intrusion, low fresh water influx from Mahi river, high evapotranspiration, and ingress of enormous amounts of effluents from industrial areas of Vadodara city. Moreover, all the hydrochemical characters are positively correlated with each other but DO and TOC were negatively correlated with $\mathrm{pH}$, salinity, chlorinity, total hardness, phosphate, COD, BOD. Palmer's indices based on presence of algal species revealed that all the three sites were organically polluted.

\section{References}

Ajitkumar, T.T.,T. Thangaradjou and I. Kannan 2006. Physico chemical and biological properties of the Muthupettai mangrove in Tamil Nadu. J. Marine Biolo. Associat. India. 48: 131-138.

Anand, N. 1998. Indian Freshwater Macro algae. Bishen Sing Mahendra Pal Singh, Dehradoon.

APHA 1989. Standard Methods for Examination of Water and Wastewater $\left(20^{\text {th }}\right.$ ed.), Washington D.C.

Beeton, A.M. 1965. Eutrophication of the St. Lawrence Great lakes. Limnol. and Oceanograp. 10: $240-254$.

Chakrapani, G.J. 2005. Major and trace element geochemistry in upper Ganga River in the Himalayas. Environ. Geol. 48: 189-201.

Cremer, H., F. Sangiorgi, F. Wagner-Cremer, V. Mcgee, A.F. Lotter and H. Visscher 2007. Diatoms (Bacillariophyceae) and dinoflagellate cysts (Dinophyceae) from Rookery bay, Florida, USA. Caribb. J. Sci. 43: 23-58.

Ekwu, A.O. and F.D. Sikoki 2004. Diversity and spatial distribution of phytoplankton in new Calabar River, Nigeria. Live syst. and sustain. Develop. 1: 25-31.

Eyre, B.D. and G. Twiggs 1997. Nutrient behaviour during post flood recovery of the Richmond river estuary northern NSW, Australia Estuarine. Coast. and Shelf Sci. 44: 311-326.

Ganapati, S.V. 1956. Hydrobiological investigations of the Hope reservoir and the Thambararaparaniriver at Papanasam, Tirunelveli district, Madras State. Indian Geo. J. 6: 1-18.

Govindasamy, C., L. Kannan and R.M. Mridula 2000. Seasonal variation in physicochemical properties and primary productivity in the coastal water biotopes of coramondel coast, India. J. Environ. Biol. 21: 1-7.

Harsha, T.S. and S.G. Malammanavar 2004. Assessment of phytoplankton density in relation to environmental variables in Gopalswamy pond at Chitradurga, Karnataka. J. Environ. Biol. 25: 113116.

Jafari, N. and G.V.R. Gand 2006. Hydrobiological study of algae of an urban freshwater rive. J. App. Sci. and Environ. Manag. 10: 153-158.

Levinton, J.S. 2001. Marine Biology, The chemical and physical environment. Oxford University Press, New York.

Likens, G.E. 1975. Primary production of inland aquatic ecosystems. In Primary production of the Biosphere (Eds. H. Lieth and R.H. Whittaker). New York.

Martin, G.D., J.G. Vijya, C.M. Laluraj, N.V. Madhu, T. Joseph, M. Nair, G.V.M. Gupta and K.K. Balachandra 2008. Fresh water influence on nutrient stoichiometry in tropical estuary, Southwest coast of India. App. Ecol. and Environ. Res. 6: 57-64.

Morias, P., M.A. Chicharo and A. Barbosa 2003. Phytoplankton dyanamics in a coastal saline lake. Acta Oecol. 24: 87-96.

Newell, G.E. and R.C. Newell 1977. Marine plankton, a practical guide. Hutchinson and Co., London.

Nirmal Kumar, J.I., B. George, N.K. Rita, R.S. Poliyaparambil and S. Vyol 2011. Assessment of water physico-chemical characteristics and statistical evaluation of Narmada Estuarine Region, Gujarat. India. J. Water and Land Dev. 16(1-6): 4348.

Nirmal Kumar, J.I., B. George, R.N. Kumar, P.R. Sajish and S. Viyol 2009. Assessment of spatial and temporal fluctuations in water quality of a tropical permanent estuarine system, Tapi, West Coast of India. App. Ecol. and Environ. Res. 7: 267-276.

Nirmal, Kumar J.I., R.N. Kumar and V. Shailendra 2010, Characterization of hydro-chemical parameters in relation to fresh water fraction ingress in tropical Narmada Estuary, Gujarat, India. An Inter. Biann. J. Environ. Sci. 4(1): 49-52.

Palmer, C.M. 1969. A composite rating of algae tolerating organic pollution. J. of Phycol. 5: 78-82.

Perumal, N.V., M. Rajkumar, P. Prumal and K.T. Rajesehar 2009. Seasonal variation of Phytoplankton diversity in the Kaduvyurestruary, Nagapattinum, South east coast of India. $J$. Environ. Biol. 30: 1035-1046. 
Philipose, M.T. 1960. Fresh water phytoplankton of Inland Fisheries, Proc. Symp. Algol ICAR, New Delhi.

Prabu, A.V., M. Rajkumar and R. Perumal 2008. Seasonal variations in physicochemical parameters in Uppanar Estuary, Cuddalore, Southeast coast of India. J. Mar. Biol. Ass. India 50: 161-165.

Pradhan, U.K, P.V. Shirodkar and B.K. Sahu 2009. Physicochemical characteristics of the coastal water of Devi Estuary, Orissa and evaluation of its seasonal changes using chemometric techniques. Curr. Sci. 96: 1203-1204.

Radhika, C.G., I. Mini and T. Gangadevi 2004. Studies on abiotic parameters of tropical fresh water lake- Vellayanilake, Trivandrum, Kerala. Poll. Res. 23(1): 49-63.

Ramnathan, A.L., V. Subramanian and P. Vaithiyanathan 1988. Phytoplankton characteristics in a polluted Bombay harbour, Thana-Bassein creek estuarine complex. Indian J. Mar. Sci. 27: 281-285.

Redekar, P.D. and A.B. Wagh 2000. Planktonic diatoms of Zuari estuary, Goa (West Coast of India). Seaw. Res. and Util. 22: 107-112.

Roy, R., A. Pratihary, G. Mangesh and S.W.A. Naqvi 2006. Spatial variation of phytoplankton pigments along the south west coast of India. Estu. Coa. and Shel. Sci. 69: 189-195.
Satpathy, K.K., A.K. Mohanty, U. Natesan, M.V.R. Prasad and S.K. Sarkar 2009. Seasonal variation in physicochemical properties of coastal waters of Kalpakkam, East coast of India with special emphasis on nutrients. Env. Monit. and Ass. 164: 153-171.

Saxeena, A. and P. Shrivastava 2001. Primary production by phytoplankton in a sewage fed lake and energy transformation to fish yield. Poll. Res. 20: 613-617.

Sharma, L.L. and N. Sarang 2004. Physicochemical limnology and productivity of Jaisam Lake, Udaypur (Rajasthan). Poll. Res. 23(1): 87-92.

Shyamalendu, B.S., S.B. Bhattacharyya, A. Mitra, B.K. Pandey and C. Amalesh 2001. Physicochemical characteristics in relation to pollution and phytoplankton production potential of a brackishwater ecosystem of Sundarbans in West Bengal. Tropi. Ecol. 42: 199-205.

Snow, G.C. and S. Taljaard 2007. Water quality in South African temporarily open /closedestuaries: A conceptual model. Afri. J. Aqu. Sci. 32: 99-111.

Somani, V. and M. Pejaver 2007. Evaluation of pollution in lake Masunda, Thane (Maharashtra). $J$. Ecobiol. 20: 163-166.

Suthers, I.M. and D. Rissik 2009. Plankton: A guide to their ecology and monitoring for water quality. CSIRO Publishing, Collingwood. 